\title{
Genpolymorfismen in de kindergeneeskundige praktijk
}

\author{
E.S.J.M. de Bont • G.H. Koppelman
}

De invloed, of bijna revolutie van genomics in de geneeskunde is mogelijk geworden met de voltooiing van het humane-genoomproject in 2003 . Het volledig in kaart brengen van het menselijke genoom heeft meer dan tien jaar in beslag genomen.

De opmaat naar dit meesterwerk is al een eeuw geleden gegeven. Mijlpalen waren de ontdekking van de mendeliaanse wetten van overerving, ${ }^{1}$ de herkenning van DNA als het erfelijke materiaal, ${ }^{2}$ het vaststellen van de structuur van DNA, ${ }^{3}$ het ontcijferen van de genetische $\operatorname{code}^{4}$ en de ontwikkeling van laboratoriumtechnieken en statistische methoden om deze hoeveelheid gegevens aan te kunnen. ${ }^{5-10}$

Aan het begin van deze eeuw heeft de kennis van het menselijke genoom een grote potentie om het inzicht op vele fronten verder uit te diepen, zoals het inzicht in fysiologische en pathofysiologische processen en in ziekten.

Het gebruik van het individuele genoom in de geneeskunde brengt ook ethische, juridische en maatschappelijke aspecten met zich mee.

Aan de hand van de mening van vooraanstaande auteurs (reviews) worden deze aspecten hier besproken. ${ }^{11-14}$

E.S.J.M. de Bont, en, $(\bowtie)$

Dr. Eveline S.J.M. de Bont, divisie kinderoncologie, Beatrix

Kinderkliniek; dr. Gerard H. Koppelman, Beatrix

Kinderkliniek, Academisch Ziekenhuis Groningen.

Correspondentieadres: Mw.dr. E.S.J.M. de Bont,

kinderoncoloog/hematoloog, divisie kinderoncologie, Beatrix

Kinderkliniek, Academisch Ziekenhuis Groningen, Postbus

30.001, 9700 RB Groningen, tel: 050-3614213, fax: 050-

3611671, e-mail: e.de.bont@bkk.azg.nl.

\section{Genoom en (patho)fysiologische processen}

Tot op heden is het vaak niet helder welke genetische instructies essentieel zijn voor de complexiteit van cellulaire processen. Allereerst zal de uitdaging zijn om structurele componenten van het menselijke genoom te identificeren. Ondanks dat DNA qua opbouw goed begrijpbaar is, is de structuur met al haar informatie en de manier waarop deze is gereguleerd nog steeds niet helder.

Slechts $1-2 \%$ van het menselijke genoom codeert voor eiwitten. ${ }^{7}$ Toch blijken de andere 98\% (non-coding regions) niet zomaar misbaar te zijn; op dit moment wordt verondersteld dat circa de helft van de non-coding regions allerlei regulerende informatie bevat die de expressie en onderlinge samenhang van de 30.000 eiwitcoderende genen op elkaar afstemt. Wat de betekenis is van de andere helft van het genoom blijft nog gissen.

De zoektocht naar het volledige repertoire aan mogelijkheden dat vastgelegd is in het genoom, staat nog aan het begin. Ook technische mogelijkheden zullen nog verder verfijnd moeten worden om dit tot volledige ontwikkeling te kunnen krijgen. Naast het identificeren van de functie van de specifieke genen in het genoom, zal het van belang worden dit type zeer complexe databestanden via aangepaste softwareprogramma's te gaan vertalen in schema's c.q. netwerken van samenwerking, waarbij uiteindelijk de organisatie van cellulaire responsroutes wordt verhelderd. Vervolgens kan worden bestudeerd in hoeverre en hoe een dergelijke organisatie bijdraagt aan fenotypische karakteristieken van bijvoorbeeld specifieke cellen, weefsels en organen.

Enkele jaren geleden is gestart met de beschrijving van de genetische variaties in de populatie, zoals singlenucleotide polymorfismen (SNP's), kleine deleties of 


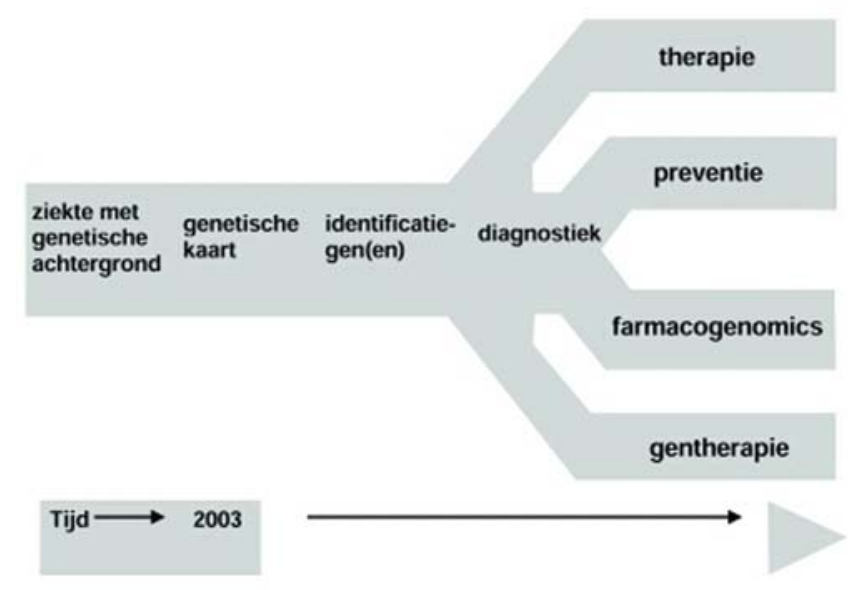

Fig. 1

inserties. Een variatie in een enkel gen wordt in toenemende mate geassocieerd met specifieke verschillen in cellulaire processen. Een variatie in thiopurine S-methyltransferase (ТРмТ) resulteert in een verminderde werkzaamheid van dit enzym in cellulaire processen die van belang zijn bij het metabolisme van thiopurinegeneesmiddelen, zoals gebruikt in leukemie (zie de bijdrage in dit themanummer over farmacogenetica). ${ }^{16}$

Het blijkt dat fenotypische verschillen op het cellulair overstijgende niveau (bijv. ziekten) vaak een multifactoriële oorzaak hebben. Ze zijn het resultaat van interacties van vele genetische factoren (genen en hun producten) en omgevingsfactoren.

\section{Genoom en geneeskunde}

Met behulp van inzicht in het menselijke genoom is het mogelijk geworden de rol van genetische factoren in ziekte en gezondheid op te helderen. Speciaal komen dan preventie, diagnose en behandeling aan bod (fig.1).

Meestal worden veel voorkomende ziekten niet gedicteerd door een enkel gen, maar door een samenspel van verschillende genen met hun organisatiestructuur en samenhang, naast verschillende omgevingsfactoren.

Cruciaal voor het succesvol zijn van dergelijke onderzoeken is een goede biologische omschrijving van de klinische entiteit waar de ziekte door gekarakteriseerd wordt en zich onderscheidt van andere nauw gerelateerde entiteiten. Het belang van heldere en afgebakende klinische entiteiten wordt in dit themanummer verder toegelicht in de bijdrage over astma en atopie. ${ }^{17}$

Anderzijds kan het zo zijn dat er binnen de huidige definitie van een klinische omschrijving toch verschillen in ernst bestaan. Zo was het al tientallen jaren geleden opgevallen dat sommige patiënten met hemofilie-A slechts matige bloedingsproblemen hadden en zelfs de volwassen leeftijd konden bereiken met een redelijk normaal dagelijks leven, terwijl andere patiënten spontane ernstige bloedingen hadden die meestal op de kinderleeftijd fataal waren. Kennis van het gen heeft veel duidelijkheid gegeven; een mutatie met als consequentie een volledig verlies van stollingsfactor VIII (FVIII) leidt altijd tot de ernstige vorm, terwijl een kleine verandering in het gen van FVIII (bijv. resulterend in verandering van één aminozuur in FVIII) slechts leidt tot milde tot matig ernstige hemofilie-A. Op deze wijze kan het individuele DNApatroon (genotype) de uitkomst (fenotype) verklaren en voorspellen. ${ }^{15}$

$\mathrm{Om}$ in ziekten met een veronderstelde al dan niet bewezen multifactoriële oorzaak de bijdrage van genetische factoren te kunnen bewijzen, zal er de komende tijd steeds meer behoefte zijn aan zeer grootschalig populatieonderzoek. Traditioneel is dit type onderzoek gefocusseerd op genen die predisponeren voor specifieke ziekten.

Er wordt nog weinig onderzoek gedaan naar genen die van belang zijn in het behoud van een goede gezondheid. Via kennis van de specifieke functies van genen zal het mogelijk worden om te bestuderen waarom bepaalde groepen individuen, ondanks blootstelling aan risicofactoren in de omgeving, toch de ziekte niet krijgen. Grote epidemiologische onderzoeken kunnen een dergelijke vraag beantwoorden.

Kennis van de genetische factoren die predispositie van de specifieke ziekte verhogen of juist verlagen, kan men inzetten voor preventieve strategieën. Als populatieonderzoek uitwijst dat er een verhoogde predispositie is, kan men de omgevingsfactoren zo trachten te wijzigen 
dat in de omgeving geen extra risico gelopen wordt. Te denken valt aan diëten, sporten, levensstijl, etc.

Op dit moment is een dergelijke preventieve strategie nog niet populatiebreed toegankelijk. Toch worden individuele gentests wel reeds commercieel via het internet aangeboden. Cruciaal zijn de exacte wetenschappelijke bepaling van het risico van het krijgen van een specifieke aandoening, en of er technische mogelijkheden zijn om tegen een relatief lage kostprijs individuele bepaling van genprofielen uit te voeren. Daarnaast blijft de vraag in hoeverre de maatschappij en/of het individu openstaat voor specifieke adviezen op het gebied van levensstijl en dergelijke. De verwachting is dat in de toekomst verschillende ziekten meer moleculair-genetisch beschreven gaan worden; een goed voorbeeld daarvan is de reclassificering van neuromusculaire aandoeningen. Dit kan leiden tot een methode waarbij ziekten in een eerdere en wellicht ook beter behandelbare fase worden gediagnosticeerd.

Naast invloed op diagnostiek en preventie heeft kennis van het genoom ook implicaties voor het therapeutisch handelen. Met de kennis van een cruciale genetische afwijking die een specifieke ziekte veroorzaakt, kan een groter arsenaal goed gefocuste middelen op de markt komen. Een van de succesverhalen is het middel imatinib

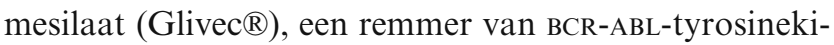
nase voor de behandeling van chronische myeloïde leukemie. Dit middel is ontwikkeld op basis van zeer gedetailleerde kennis van de genetische oorzaak van deze ziekte. De verwachting is dat deze ontwikkeling nog meer succesverhalen zal gaan opleveren.

Voor veel voorkomende ziekten zal de farmaceutische industrie ongetwijfeld dergelijke geneesmiddelen ontwikkelen. Voor zelden voorkomende ziekten is het echter belangrijk dat universiteiten gemakkelijk toegang krijgen tot de technische mogelijkheden om veelbelovende prototypen van geneesmiddelen te kunnen testen. Op individueel niveau kan een genetisch profiel aangeven dat bepaalde middelen minder goed zullen werken. In het deel farmacogenetica van dit themanummer wordt daar dieper op ingegaan. ${ }^{16}$ Individuele genetische profielen houden de belofte in dat in de toekomst behandelingen meer geïndividualiseerd kunnen worden gegeven.

\section{Voor- en nadelen van genoomonderzoek voor de maatschappij}

Veel mensen zien de waarde van genomics op het gebied van gezondheid en ziekte. Recent heeft het zijn waarde weer bewezen als identificatiemiddel voor nieuwe pathogenen, zoals tijdens de SARS (severe acute respiratory syndrome)-epidemie.
Toch zal genomics ook zijn invloed hebben op andere aspecten van de samenleving, zoals sociaal, ethisch en/of juridisch. Zo ziet de politiek de keerzijde: het mogelijke misbruik van de informatie als deze tot het individu herleidbaar is. Gedacht kan worden aan de premie van ziektekostenverzekeringen of het aannamebeleid van werkgevers. Het vaststellen van regulering tegen genetische discriminatie is een van de randvoorwaarden die politiek opgelost moeten worden. Moeten scholen geïnformeerd worden over de predispositie voor bijvoorbeeld ADHD of andere gedragsproblemen? Het vrij kunnen verkrijgen van individuele genetische tests vraagt om bewaking van kwaliteit.

\section{Conclusie}

Dit themanummer beperkt zich tot die genetische variaties die voor bepaalde, veel voorkomende ziekten op de kinderleeftijd bekend zijn of zeer veelbelovend zijn, zoals op het gebied van astma, infectieziekten, diabetes, en inflammatoire en immunologische aandoeningen. Tevens wordt een review gewijd aan de beïnvloeding van de farmacokinetiek en farmacodynamiek door genetische varianten. Steeds zal het doel zijn weer te geven in hoeverre etiologie, diagnose en/of behandeling zich hebben verdiept op basis van genetische kennis. Ter introductie van deze meer ziektegerelateerde bijdragen, vindt $\mathrm{u}$ een verdieping in de genetica die zich richt op de achtergronden en mogelijkheden om onderzoek in dit gebied te doen. De verklarende lijst met begrippen en afkortingen kunnen voor de verschillende bijdragen worden gebruikt.

\section{literatuur}

Mendel G. Versuche über Pflanzen-Hybriden. Verhandlungen des naturforschenden Vereines, Abhandlungen, Brünn 1866;4:347.

Avery OT, MacLeod CM, McCarty M. Studies of the chemical nature of the substance inducing transformation of pneumococcal types. Induction of transformation by a desoxyribonucleic acid fraction isolated from Pneumococcus Type III. J Exp Med 1944;79:137-58.

Watson JD, Crick FHC. Molecular structure of nucleic acids: A structure for deoxyribose nucleic acid. Nature 1953;171:737.

Nirenberg MW. The genetic code: II. Sci Am 1963;208:80-94.

Jackson DA, Symons RH, Berg P. Biochemical method for inserting new genetic information into DNA of Simian Virus 40: circular SV40 DNA molecules containing lambda phage genes and the galactose operon of Escherichia coli. Proc Natl Acad Sci USA 1972;69:2904-9.

Cohen SN, Chang AC, Boyer HW, Helling RB. Construction of biologically functional bacterial plasmids in vitro. Proc Natl Acad Sci USA 1973;70:3240-4. 
Lander ES, Linton LM, Birren B, et al., The International Human Genome Sequencing Consortium. Initial sequencing and analysis of the human genome. Nature 2001;409:860-921.

Sanger F, Coulson AR. A rapid method for determining sequences in DNA by primed synthesis with DNA polymerase. J Mol Biol 1975;94:441-8.

Maxam AM, Gilbert W. A new method for sequencing DNA. Proc Natl Acad Sci USA 1977;74:560-4.

Smith LM, Sanders JZ, Kaiser RJ, et al. Fluorescence detection in automated DNA-sequence analysis. Nature 1986; 321:674-9.

Collins FS, Green ED, Guttmacher AE, Guyer MS, US National Human Genome Research Institute. A vision for the future of genomics research. Nature 2003;422:835-47.

Burke W. Genomics as a probe or disease biology, N Engl J Med 2003;349:969-74.
Guttmacher AE, Collins FS. Welcome to the genomic era, N Engl J Med 2003;349:996-8.

Haga SB, Khoury MJ, Burke W. Genomic profiling to promote a healthy lifestyle: not ready for prime time. Nat Genet 2003;34:347-50.

Hoyer LW. Hemophilia A. N Engl J Med 1994;330:38-47.

Wiersma HE, Koopmans RP, Bos AP, et al. Het juiste geneesmiddel voor de juiste patiënt: Farmacogenetica in de kindergeneeskundige praktijk. Tijdschr Kindergeneeskunde 2004; 72:190-197.

Reijmerink NE, Koppelman GH, Postma DS. Astma en atopie: complexe genetische ziekten. Tijdschr Kindergeneeskunde 2004;72:172-179. 